\title{
Human Bot Fly, torsalo (Central America), moyocuil (Mexico), berne (Brasil), mucha (Colombia, mirunta (Peru), and ura (Argentina, Paraguay, and Uruguay), Dermatobia hominis (Linnaeus, Jr.) (Insecta: Diptera: Oestridae) ${ }^{1}$
}

Stephanie K. Larrick and C. Roxanne Connelly ${ }^{2}$

\section{Introduction}

The human bot fly, Dermatobia hominis (Linnaeus Jr., 1781), is a large, densely haired fly that looks like a bumblebee (Kahn 1999). The human bot fly is native to Central and South America. The fly is not known to transmit disease-causing pathogens, but the larvae of $D$. hominis will infest the skin of mammals and live out the larval stage in the subcutaneous layer, causing painful pustules that secrete fluids. The infestation of any fly larvae inside the body is known as myiasis.

Cases of human D. hominis myiasis reported from non-indigenous people are diagnosed when travelers bring the parasite back with them from Central and South America. Haruki et al. (2005) reported 33 cases of $D$. hominis in Japan from 1974-2005 as a result of overseas travel to Central and South America. One third of the reported cases occurred during the last six years of the study. Six different studies have documented seven reported cases of $D$. hominis myiasis in the United States since 1999 (Lawson et al. 2005, Liebert et al. 2004, Maier et al. 2004, Marty et al. 2005, Millikan 1999, Sampson et al. 2002). All the patients with confirmed D. hominis myiasis had recently been to Central or South America.

\section{Distribution}

Dermatobia hominis is indigenous from Mexico in the north to Paraguay and northeast Argentina in the south.

\section{Description}

Adult: The adult bot fly is 12 to $18 \mathrm{~mm}$ long with a wide array of colors (Kahn 1999, Sampson et al. 2001). The face is yellow with a metallic blue abdomen and orange legs and each body segment is

1. This document is EENY 440, one of a series of the Entomology and Nematology Department, Florida Cooperative Extension Service, Institute of Food and Agricultural Sciences, University of Florida. Original publication date September 2008. Visit the EDIS Web Site at http://edis.ifas.ufl.edu.

2. C. Roxanne Connelly, Associate professor and extension medical entomologist, Department of Entomology, at the Florida Medical Entomology Lab, 200 9th St. SE, Vero Beach Florida 32962: and Stephanie K. Larrick, graduate assistant, Department of Entomology, at the Florida Medical Entomology Lab, 200 9th St. SE, Vero Beach Florid; Cooperative Extension Service Institute of Food and Agricultural Sciences, University of Florida, Gainesville, 32611.

The Institute of Food and Agricultural Sciences (IFAS) is an Equal Opportunity Institution authorized to provide research, educational information and other services only to individuals and institutions that function with non-discrimination with respect to race, creed, color, religion, age, disability, sex, sexual orientation, marital status, national origin, political opinions or affiliations. U.S. Department of Agriculture, Cooperative Extension Service, University of Florida, IFAS, Florida A. \& M. University Cooperative Extension Program, and Boards of County Commissioners Cooperating. Millie Ferrer-Chancy, Interim Dean 


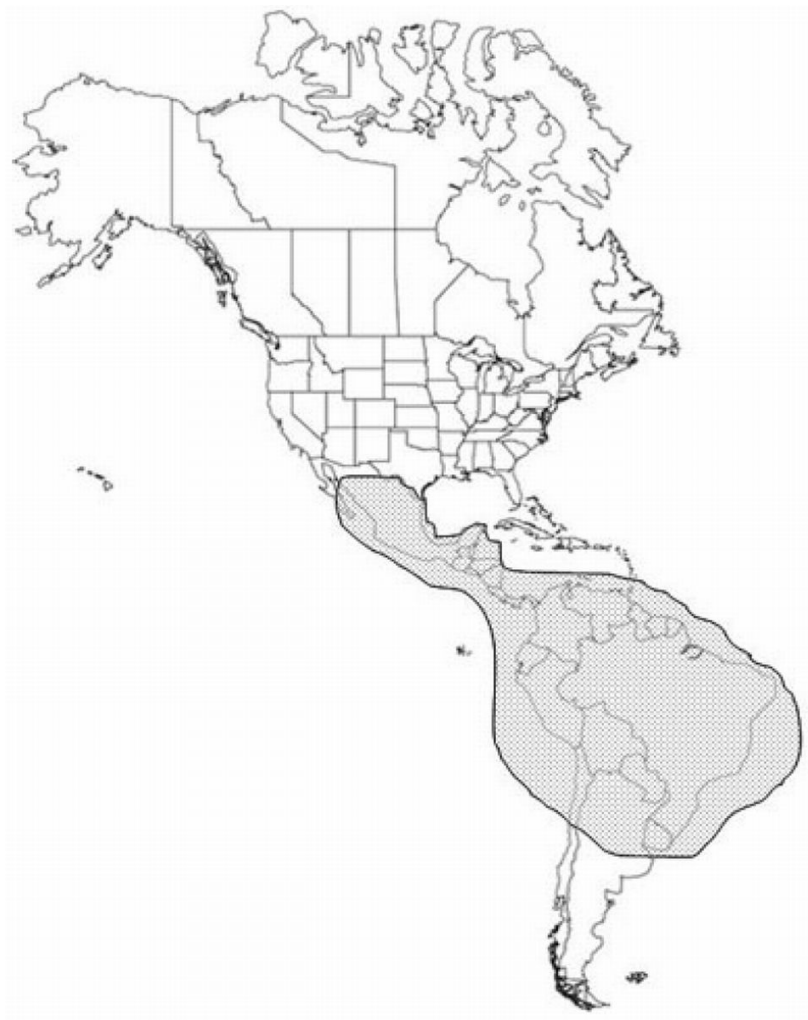

Figure 1. The geographical distribution of the human bot fly, Dermatobia hominis (Linnaeus f.). Credits: C. Roxanne Connelly, University of Florida

covered with hairs which give the fly a bumblebee appearance (Khan 1999).

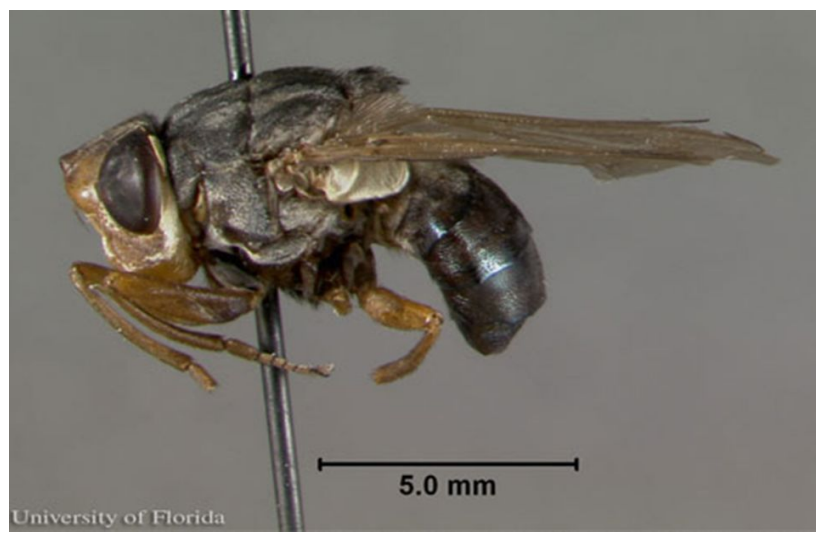

Figure 2. Lateral view of an adult human bot fly, Dermatobia hominis (Linnaeus Jr.). Credits: Lyle J. Buss, University of Florida

Egg: The egg of the bot fly is creamy colored and oval in shape, and is attached to different species of blood-feeding insects captured by the female bot fly. The eggs, usually attached to the ventral side of the body, hatch when the insect carrying the eggs begins to blood feed on a warm-blooded host.

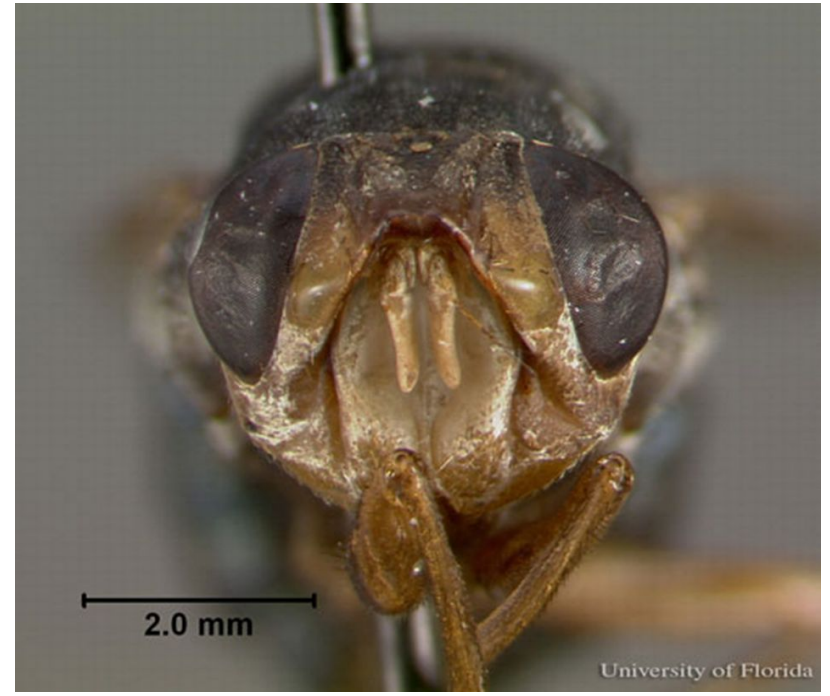

Figure 3. Frontal view of an adult human bot fly, Dermatobia hominis (Linnaeus Jr.). Credits: Lyle J. Buss, University of Florida

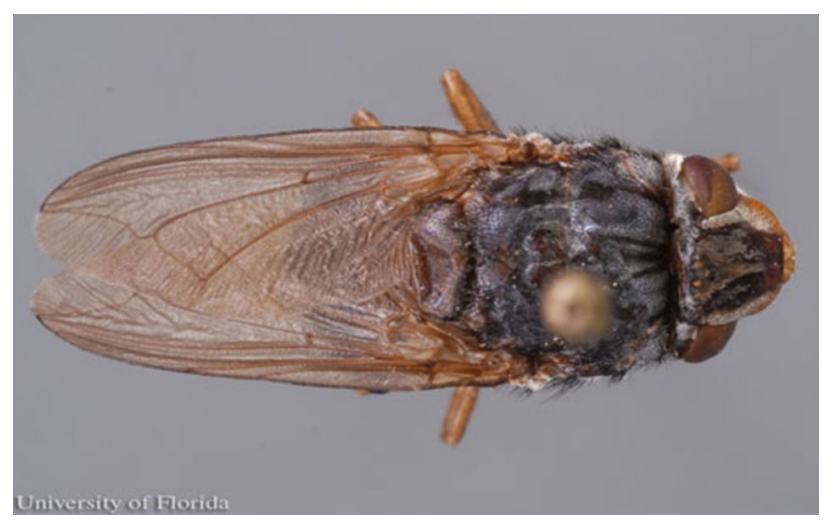

Figure 4. Dorsal view of an adult human bot fly, Dermatobia hominis (Linnaeus Jr.). Credits: Lyle J. Buss, University of Florida

Larva: The larva, or white maggot, goes through three instars once in the mammalian host. Each instar develops a distinctive shape. The first instar is worm-like with a bulbous end. The second instar larva has a bottle-neck shape. The third instar is cylinder shaped. Each instar possesses backward projecting spines that encircle the thorax.

Pupa: The puparium may exhibit the prominent anterior spiracles of the third instar larva.

\section{Life Cycle}

Eggs: Female D. hominis adults deposit their mature eggs on a blood-feeding arthropod, usually a mosquito or a tick, that is captured by the bot fly in flight. This behavior is known as phoresy (Safdar et 


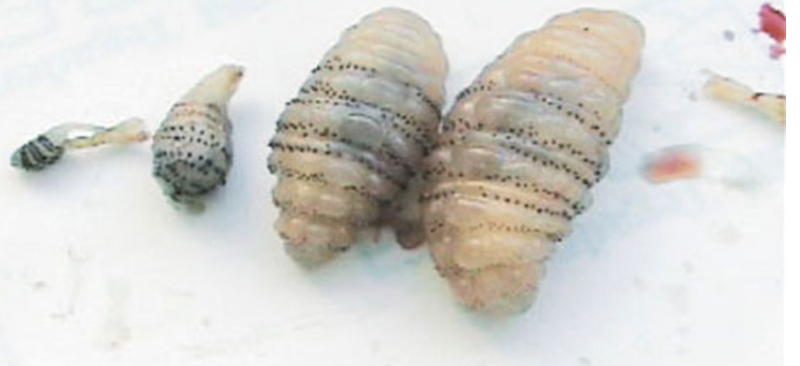

Figure 5. Left to right - 1st, 2nd, early 3rd, and late 3rd instar larva of the human bot fly, Dermatobia hominis (Linnaeus Jr.). Credits: Francisco M. Marty, M.D. and Kristen R. Whiteside, B.S., Brigham and Women's Hospital, Boston, MA

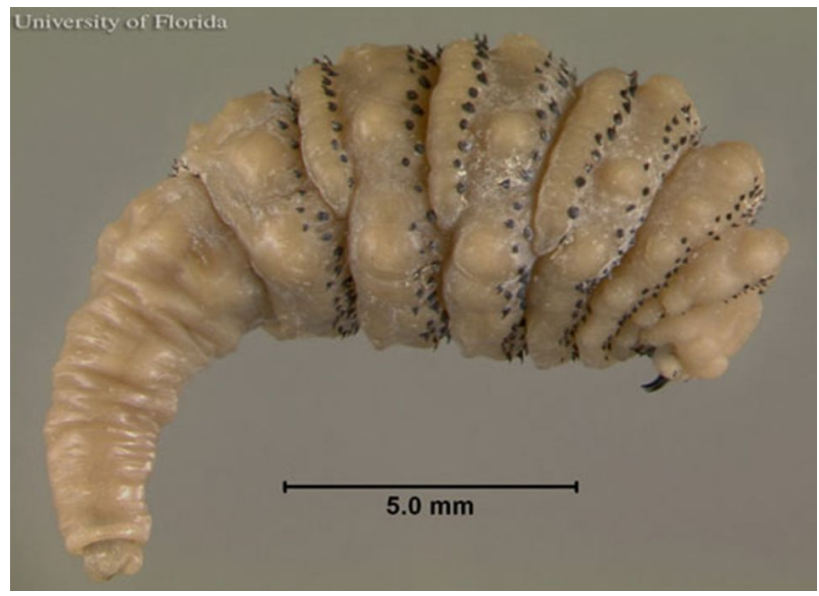

Figure 6. Third instar larva of the human bot fly, Dermatobia hominis (Linnaeus Jr.), lateral view. Credits: Lyle J. Buss, University of Florida

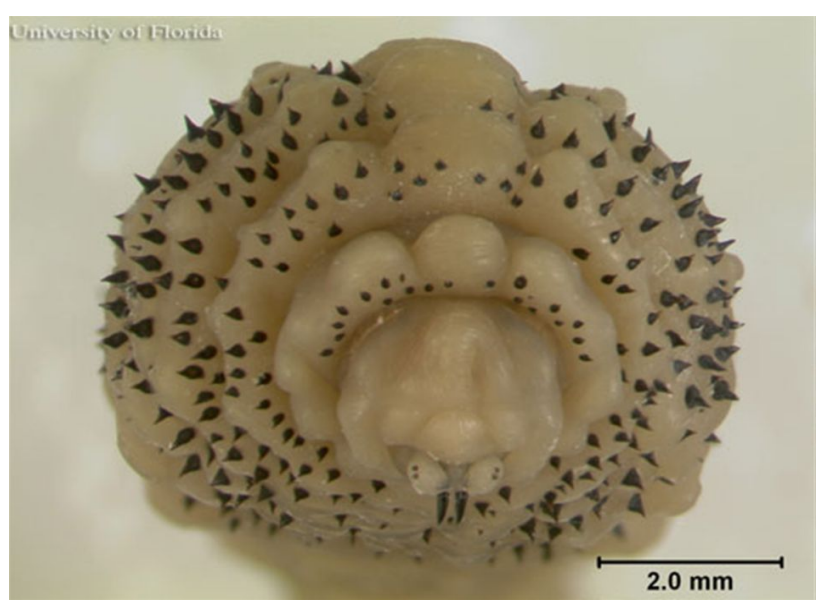

Figure 7. Third instar larva of the human bot fly, Dermatobia hominis (Linnaeus Jr.), frontal view Credits: Lyle J. Buss, University of Florida

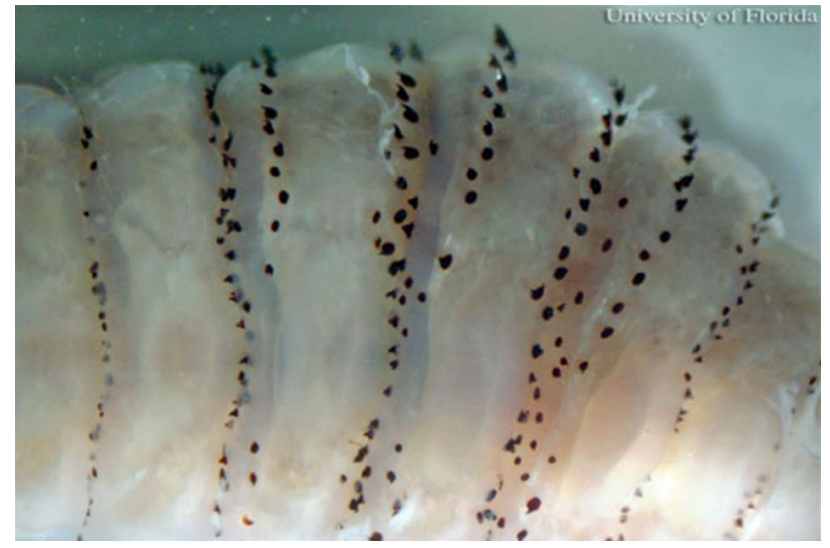

Figure 8. Backward projecting spines on larva of the human bot fly, Dermatobia hominis (Linnaeus Jr.). Credits: C. Roxanne Connelly, University of Florida

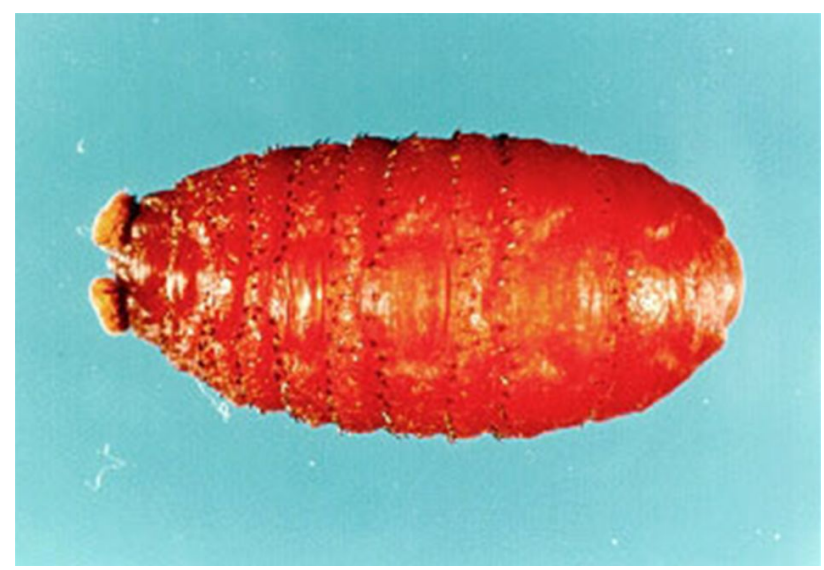

Figure 9. Pupa of the human bot fly, Dermatobia hominis (Linnaeus Jr.). Credits: Marcelo de Campos Pereira, University of Sao Paulo

al. 2003). As the vector takes a blood meal, the bot fly eggs react to the change in temperature and hatch.

Larvae: The larvae enter the skin through the bite wound or hair follicles, where it then burrows into the skin. The larvae breathe through two posterior spiracles which lie flush with the skin of the host. A study by Pereira et al. (2001) showed that in rats, it took two days for the larvae to reach the subcutaneous tissue. After the seventh day of infestation, the larvae molt to the second instars, and then to third instar after eighteen days. After approximately thirty days, the third instar larvae, which can grow to be relatively large (Fig. 7), crawl out of the host to pupate in the soil. In general, the life of the larvae inside the host is five to 12 weeks (Acha and Szyfres 1994). The larva feed on tissue exudates (Haruki et al 2005 and Kahn 1999). 


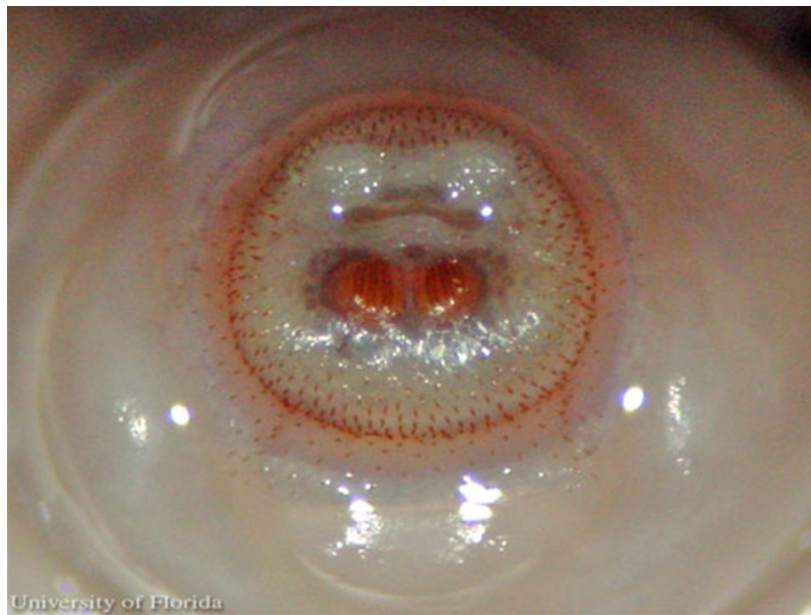

Figure 10. Posterior spiracles of the larva of the human bot fly, Dermatobia hominis (Linnaeus Jr.). Credits: C. Roxanne Connelly, University of Florida

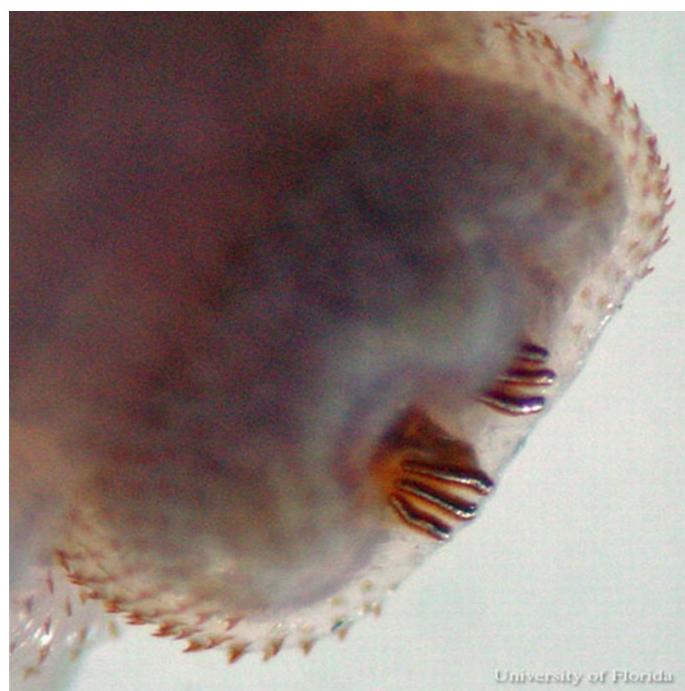

Figure 11. Side view of posterior spiracles of the larva of the human bot fly, Dermatobia hominis (Linnaeus Jr.). Credits: C. Roxanne Connelly, University of Florida

Pupae: Pupation takes place in the ground and the pupae do not feed. Adults will emerge after two to three weeks.

Adults: Bot flies emerge from the pupal cases, and their extremely sensitive antennae (making up for poor vision) allow the males and females to find each other quickly (Fernandes et al. 2004). During the adult stage, D. hominis does not feed.

\section{Hosts}

The most common hosts for the human bot fly are cattle and dogs. However, they are found in many warm-blooded animals including buffalo, cattle, cats, dogs, humans, monkeys, pigs, rabbits, and sheep.

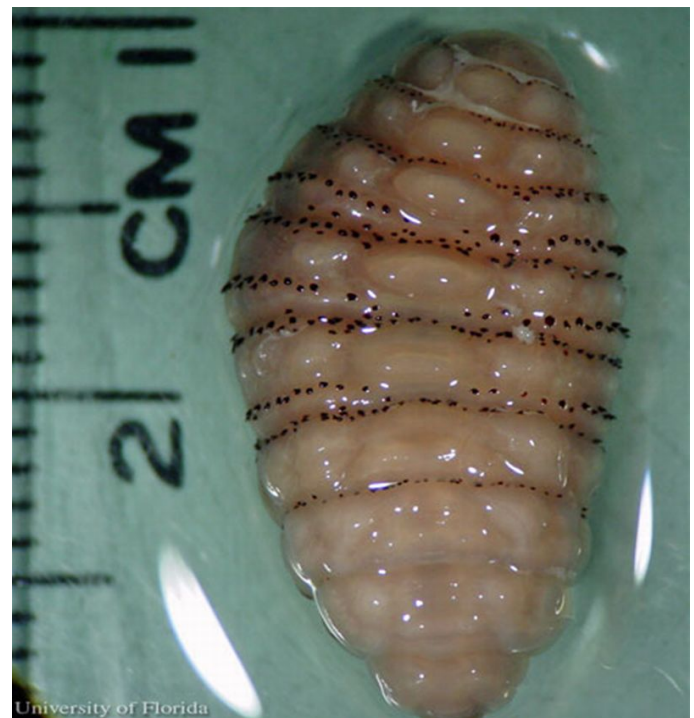

Figure 12. Third instar larva of the human bot fly, Dermatobia hominis (Linnaeus Jr.). Credits: C. Roxanne Connelly, University of Florida

\section{Symptoms and Treatment}

Dermatobia hominis larvae cause a raised lesion in the skin that becomes hard and sometimes painful. In some cases the patients can feel the larvae moving when they shower or cover the wound (Haruki et al. 2005, Sampson et al. 2001). The host reacts with elevated white cell counts and a high amount of macrophages can be found around the wound. For this reason, the lesion often secretes pus.

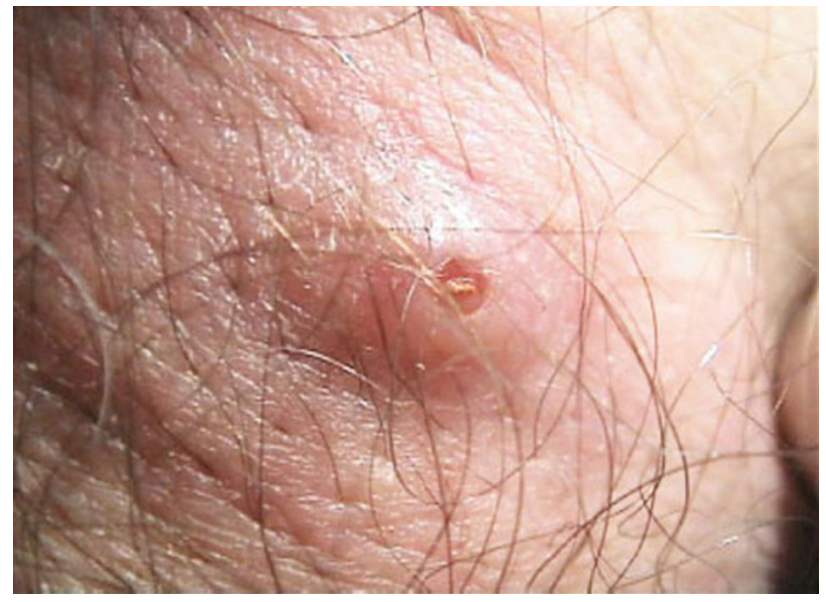

Figure 13. Raised lesion on the skin caused by the presence of a larva of the human bot fly, Dermatobia hominis (Linnaeus Jr.). Credits: Francisco M. Marty, M.D. and Kristen R. Whiteside, B.S., Brigham and Women's Hospital, Boston, MA

There are several treatment options for treatment of $D$. hominis myiasis. The most conventional way of 
removing the larvae is with a simple surgical procedure that includes local anesthesia. Using a scalpel to cut a slit to enlarge the wound, the larvae can be taken out.

Dermatobia hominis survives in its host by breathing through spiracles that are flush with the skin. In order to coax the larva out, the spiracles need to be covered. They can be covered with bacon, petroleum jelly, beeswax, or any other thick substance that prevents the larvae from breathing. The larvae will come up out of the lesion to breathe allowing it to be removed with forceps.

In some cases the larva maybe popped out by applying pressure around the wound. Tamir et al. (2003b) cited a technique that used two wooden spatulas to apply pressure to pop the larva out. There may be some difficulty with this method due to the spines that anchor the larvae in the wound.

Several authors (Diaz et al. 2006, Kahn 1999, Safdar et al. 2003, Tamir et al. 2003b) have cited the use of lidocaine injections underneath the cyst. This creates pressure that pushes the larva out.

After any of these procedures, antibiotics are given to prevent infection. The wound should heal in one to two weeks with little or no scarring.

\section{Management}

Due to the increase in travelers to Central and South America, it is important to carefully monitor and control the vector population. Additionally, travelers to these regions need to take preventive measures, including applying insect repellent and wearing protective clothing (Diaz et al. 2006; Maier and Honigsmann 2004).

UF/IFAS Recommended Mosquito Repellents http://edis.ifas.ufl.edu/IN419

\section{Selected References}

- Acha P, Szyfres B. 1994. Zoonoses and communicable disease common to man and animals. 2nd Edition. Scientific Publication No. 503. Pan American Health Organization. WHO, Washington, D.C. 963 pp.
- Cornet MM, Florent A, Lefebvre C, Wertheimer CP, Bangs M, Bouvet A. 2003. Tracheopulmonary myiasis caused by a mature third-instar Cuterebra larva: case report and review. Journal Clinical Microbiology 41: 5810-5812.

- Diaz JH. 2006. The epidemiology, diagnosis, management, and prevention of ectoparasitic diseases in travelers. Journal of Travel Medicine 13: 1195-1982.

- Fernandes FF, Linardi PM, Chiarini-Garcia H. 2002. Morphology of the antenna of Dermatobia hominis (Diptera: Cuterebridae) based on scanning electron microscope. Journal of Medical Entomology 39: 36-43.

- Fernandes FF, Chiarini-Garcia H, Linardi PM. 2004. Scanning electron microscopy studies of sensilla and other structures of adult Dermatobia hominis (L. Jr., 1781) (Diptera:Cuterebridae). Journal of Medical Entomology 41: 552-560.

- Haruki K, Hayashi T, Kobayashi M, Katagiri T, Sakurai Y, Kitajima T. 2005. Myiasis with Dermatobia hominis in a traveler returning from Costa Rica: review of 33 cases imported from South America to Japan. Journal of Travel Medicine 12: 285-288.

- Kahn DG. 1999. Myiasis secondary to Dermatobia hominis (Human Botfly) presenting as a long-standing breast mass. Archives of Pathology and Laboratory Medicine 123: 829-831.

- Lawson RD, Rizzo M. 2005. Digital infestation with the human bot fly. Journal of Hand Surgery 30B: 490-491.

- Lang T, Smith DS. 2003. Wiggling subcutaneous lumps. Clinical Infectious Diseases 37: 2087-2088.

- Liebert PS, Madden RC. 2004. Human botfly larva in a child's scalp. Journal of Pediatric Surgery 39: 629-630.

- Maier H, Honigsmann H. 2004. Furuncular myiasis caused by Dermatobia hominis, the 
human bot fly. Journal of the American

Academy of Dermatology 50: S26-S30.

- Matera G, Liberto MC, Larussa F, Barreca GS, Foca A. 2001. Human myiasis: an unusual imported infestation in Calabria, Italy. Journal of Travel Medicine 8: 103-104.

- Marinho CR, Barbosa LS, Granthon de Azevedo AC, de Carvalho Querizo MM, Valgode MA, Aguiar Coelho AM. 2003. Hemilucilia segmentaria (Fabricius, 1805) (Diptera: Calliphoridae) as new biological vector of eggs of Dermatobia hominis (Linnaeus Jr., 1781) (Diptera: Oestridae) in Reserva Biologica do Tingua, Rio de Janeiro, Brazil. Memórias do Instituto Oswaldo Cruz 98: 937-938.

- Marty FM, Whiteside KR. 2005. Myiasis due to Dermatobia hominis (Human Botfly). New England Journal of Medicine 23: 352.

- Millikan LE. 1999. Myiasis. Clinical Dermatology 17: 191-195.

- Pereira MCT, Leite VHR, Leite ACR. 2001. Experimental skin lesions from larvae of the bot fly Dermatobia hominis. Medical and Veterinary Entomology 15: 22-27.

- Rossi MA, Zucoloto S. 1973. Fatal cerebral myiasis caused by the tropical warble fly, Dermatobia hominis. American Journal of Tropical Medical Hygiene 22: 267-269.

- Rutledge CR, Day JF. 2008. Mosquito Repellents. EDIS. http://edis.ifas.ufl.edu/IN419 (30 June 2008).

- Safdar N, Young DK, Andes D. 2003. Autochthonous furuncular myiasis in the United States: case report and literature review. Clinical Infectious Diseases 36: e73-80.

- Saliba EK, Oumeish YO, Oumeish I. 2002. Epidemiology of common parasitic infections of the skin in infants and children. Clinical Dermatology 20: 36-43.
- Sampson C E, MaGuire J, Eriksson E. 2001. Botfly myiasis: case report and brief review. Annals of Plastic Surgery 46: 150-152.

- Schwartz E, Gur H. 2002. Dermatobia hominis myiasis: an emerging disease among travelers to the Amazon Basin of Bolivia. Journal of Travel Medicine 9: 97-99.

- Tamir J, Haik J, Orenstein A, Schwartz E. 2003a. Dermatobia hominis myiasis among travelers returning from South America. Journal of the American Academy of Dermatology 48: 630-632.

- Tamir J , Haik J, Schwartz E. 2003b. Myiasis with Lund's fly (Cordylobia rodhaini) in travelers. Journal of Travel Medicine 10: 293-295.

- Villarino M A, Garcia O, Fussell W, Preston K, Wagner GG. 2003. An initial survey of the cattle grub Dermatobia hominis (L. Jr.) in Nicaragua. Preventive Veterinary Medicine 61: 333-338. 